\title{
The Student's Experience of Attending Large Classes in a South African Higher Education Context
}

\author{
Dr Pauline Machika
}

Centre for Academic Development, Vaal University of Technology

Email:paulinema@vut.ac.za

\section{Dr Christel Troskie-de Bruin}

Centre for Higher and Adult Education, Stellenbosch University, South Africa Email: asev@icon.co.za

\section{Dr Ruth M. Albertyn}

Centre for Higher and Adult Education, Stellenbosch University, South Africa Email: rma@sun.ac.za

\section{Doi:10.5901/mjss.2014.v5n16p375}

Abstract

The increase in numbers of students entering South African universities results in the challenge of effectively managing large groups of students in classrooms. Previous research has focused on resourcing and the manner in which knowledge can be conveyed in large classes. To date not much research has been conducted on the student experience within a large class setting at South African higher education institutions. To make provision for responsible massification of higher education that does not affect the quality of student learning negatively, it is necessary to identify the perspective of students on teaching and learning in large classes. A descriptive exploratory study was undertaken using quantitative data derived from a questionnaire. Undergraduate students were asked to provide information related to their experiences of various aspects in the largest class they attend, such as physical environmental, teaching in class, methods/activities, learning and assessment. The results indicate that the students' level of academic independence determines how well they cope in a large class and the competence and enthusiasm of the lecturer influences whether they attend these classes regularly. It is recommended that teaching and learning methods that can develop students' ability for independent learning be gradually introduced in large classes.

\section{Introduction}

Despite the shift from "open access" to "access with academic success", graduation outputs in South African higher education remain low (Scott et al 2007). The Higher Education Act 101 of 1997, (DoE 2001) makes provision for the massification of higher education in South Africa. This has resulted in large numbers of students entering universities, which creates the challenge to effectively manage hundreds of students together in large lecture halls or classrooms. Several aspects related to the large class phenomenon are known and accepted by South African academics. These aspects include increased resource requirements, in particular specialised lecturing skills and sufficient and appropriate facilities that allow a variety of teaching methods, a flexible approach to seating and improved technological resources (Biggs 1999). Although there is a notable focus on resourcing and the manner in which knowledge can be conveyed in large classes, very little is known about the impact of large class sizes on their learning from the perspectives of students attending the these classes. Without understanding the phenomenon from a student perspective, lecturers will not know if the goals of the teaching and learning experience have been achieved. These goals extend beyond knowledge acquisition alone. The greater purpose of studying in higher education is to produce students who are able to communicate effectively, have strong interpersonal and social awareness, are creative problem solvers and are able to display well-developed leadership skills (Engelbrecht 2003). Large classes are not the ideal environment to develop these skills. Therefore, the planning of teaching and learning in a large class setting should create opportunities to develop the required skills. To achieve the desired outcomes set by the HE institution, it is necessary to be aware of both lecturers' and students' experience of large classes. 
To date not much research has been conducted on the student experience within a large class setting at South African higher education institutions. To make provision for responsible massification that does not affect education and the quality of student learning negatively, it is necessary to identify the needs and perspective of students who already attend large classes. This article aims to contribute to a better understanding of how students experience large classroom teaching by focusing on their view of issues concerning the attendance of a large class at a comprehensive higher education institution in South Africa.

In the next section challenges experienced by lecturers and students in large classes are discussed. This is followed by a description of the survey of undergraduate students by means of an electronic as well as a paper-based questionnaire. The main trends in the findings are discussed after presentation of the results and the article concludes with some recommendations for further research.

\section{Theoretical Framework}

The challenges of teaching large classes relate to size, academic performance, student engagement, teaching and learning problems and physical aspects. The size of a large class is relative. Some lecturers view a class size of 40 to 60 students as a large class (Harpp 1994), for some a class with 30 students is considered large, while for others the number would be 200 or more. Studies done internationally reflect that a 'large class' comprises between 150 and 300 students (Nicol \& Boyle 2003; Yang 2008).

Research results on the relationship between class size and academic performance vary. (Toth \& Montagne 2002)

have identified conflicting results concerning the relationship between class size and academic performance.

Earlier research highlights that student engagement with the lecturer is of crucial importance to ensure the academic success of students (Biggs 1999; Carbone \& Greenberg 1998). The increase of class size often results in limited exchanges occurring between students and lecturers with the consequence that students remain anonymous and become passive (Kyne 2010). Without appropriate engagement with lecturers, students often experience difficulty when make meaning of the subject field that they have not been previously exposed to (Kuh, Kinzie, Shuh \& Whitt 2010; WolfWendel et al 2009). The large class has implications for teaching and learning related to student and lecturer interaction, student learning and responsibility, teaching and feedback.

A large classroom setting is not conducive to the development of interpersonal dialogue as a significant mode of dialogue that ensures teaching and learning (Gorsky et al 2011). Structural resources, like seating arrangements and the physical environment of the classroom, might hamper the scope for interpersonal dialogue between a lecturer and a student, as well as among students.

According to (Gorsky et al 2011) students view lecturers as part of the structural resources - although as a resource for information. This emphasises the role of the lecturer in enhancing student learning (Wenglinsky 2000; OECD

2008) and implies that the lecturer as part of the whole setting contributes to the level of interaction in the class. (Tinto2007) emphasises that the interaction among students, as well as between students and the lecturer should be of high quality, otherwise it could result in the students failing or dropping out.

Therefore the ideal is to create an environment in which students are encouraged to not only focus on what should be learnt, but also on how they can learn it effectively (Bovilla et al 2011). This is however challenging in the context of a large class especially since many students attending large classes prefer traditional lecturing, where the lecturer dominates and the students remain passive during the teaching and learning process (Gibbs, 1992). This kind of practice often leads to the attendance of lectures dwindling to either irregular or no class attendance during the semester.

Further problems associated with large classes are that students in large class lectures do not prepare for class (Ward \& Jenkins 1992) arrive late and/or leave early or display distracting behaviour during the lecture. University life for first year students is often experienced as being insecure and muddled (Ramsden 2003). A large class context could pose additional challenges that might cause both first year students and lecturers to feel disempowered and demotivated.

Recent research emphasises the different perceptions of what good teaching is (Rowe 2011). From a traditional perspective, good teaching is evident when the objective is to present information; the material is well organised in a particular way; the lecturer presents alternative points of views or clarifies issues in preparation for discussion (Clark et al

2008). From an active learning perspective teaching is considered to be good when the lecturer is able to involve students more directly in the teaching and learning process. Central to good teaching is ensuring that the correct teaching and learning approach occurs within the appropriate context and the lecturer achieves the instructional goals within the teaching and learning context (Mulryan-Kyne 2010).

Regular feedback from the lecturer is part of the teaching and learning process. Feedback becomes difficult with the increasing student: staff ratios of large class sizes. In first year classes, it is particularly difficult for academic staff to 
provide the level of personalised feedback that students need (Rowe 2011). To manage this, alternative methods and structures are put in place, but what gets lost in the process is the most significant element in inter-personal dialogue, namely, the human being (Gorsky \& Caspi 2005). Providing feedback to students in a large class can be demanding for a single lecturer. Research by (Gibbs 1992) has shown that students in large classes often voice their dissatisfaction with the inadequate feedback received from lecturers, the lack of adequate classroom facilities and with the classroom environment.

Ward and Jenkins, (1992) explain that some of the problems experienced by lecturers include dealing with large numbers of students entering and exiting the lecture room, which often results in teaching sessions starting late, dealing with noise levels during in-class tasks and dealing with the large volume of marking and student feedback. All these factors might lead to students becoming reluctant to attend classes.

In the light of the above challenges, it becomes important to understand the experiences of students who are part of a large classroom setting, since it can provide insight that might help the university to plan proactively to facilitate the institution's preferred student experience. Once students are given an opportunity to voice their opinions on large classroom teaching, new and useful insights might be provided which could contribute to the quality of teaching and learning. The student voice is premised on notions that students have a unique perspective on teaching and learning and that they should be invited to share their insights, views and perspectives (Fielding 2001; Rudduck 2007).

\section{Context of the Study}

The research on which this paper is based was done at the University of Johannesburg (UJ). The UJ has been experiencing growth in student numbers ever since its inception in 2005. This is the result of the government's requirement to make higher learning accessible. The UJ enrolled 36128 students in 2002, in 2005 there were 45544 and in 2010 the number of students has increased to 48258 (UJ HEDA System 2002-2010). This growth has implications for maintaining the quality of teaching, learning and assessment.

\section{Research Methodology}

A descriptive exploratory study was undertaken using quantitative data derived from a questionnaire. The questionnaire was designed based on literature reviewed. The students were asked to complete demographic information related to year of study, age, gender and size of largest class. A dendrogram was constructed based on concepts relevant to teaching and learning in large classes. The dimensions covered included physical environmental aspects, teaching in class, methods/activities, learning and assessment. The questionnaire consisted of 50 statements with response options formulated on a 4-point Likert scale ('strongly disagree' to 'strongly agree') with a 'not applicable' column included. The questionnaire was scrutinised by two experts in the field and then piloted among eight undergraduate students at another university. Adaptations were made to the questionnaire based on the feedback received.

Undergraduate students in the Faculty of Economic and Financial Sciences were targeted for the study. As this faculty at UJ has the largest number of registered students (the figures for 2010 for undergraduates were 4695 it was selected for investigation of the experiences and challenges faced in teaching large classes at the university. The students completed a questionnaire to indicate their experiences of attending large classes. The questionnaire was made available electronically through the university's learning management system, Edulink, and hard copies were distributed in class. Students were requested to only complete one questionnaire and to answer the questionnaire in relation to the largest class they attend. The intent with this study was not to evaluate responses according to the particular module, but rather according to the dimensions of interest to teaching and learning in general.

\section{Ethical Considerations}

The purpose of the study was explained to participants and they were informed that participation was voluntarily. Confidentiality and anonymity were assured. Permission for this study was obtained from the Ethics Committee residing within Academic Development and Support Centre within UJ.

\section{Data Analysis}

The analysis of the quantitative data captured from the questionnaires was done using Statistica and involved descriptive statistics (frequencies and means), ANOVA and Spearman correlations. The Cronbach Alpha was applied to test the 
reliability of the main dimensions on the questionnaire.

\section{Results}

\subsection{Characteristics of the respondents}

There were 2988 students who responded but not all students completed all the questions on the questionnaire. The missing data could reflect a disadvantage of electronic surveys, which is a limitation of the study. Some students started completing the questionnaire and gave up halfway. It is not certain if it was due to questionnaire fatigue or whether students had limited time and had intended to come back and complete the questionnaire, but never returned. Most respondents (61\%) were in their first year of study while only $6 \%$ of them were third year students. The majority (72\%) reported that the size of the largest class they attend was over 300. The respondents were mainly between 19 and 21 years of age, but some (13\%) were 18 years and younger and only 3\% were over 25 years of age. More females (59\%) than males answered the questionnaire.

\subsection{Physical environmental aspects}

The greatest challenges regarding physical environmental aspects seem to be group size interfering with learning, inability to see the lecturer and loss of time when entering class. The ANOVA analysis indicated that there were statistically significant differences in the year groupings' experiences of physical aspects $(p<0.01)$. Third year students were most positive and second year students least positive. There was also a statistically significant difference in the size of class and the students' experience of physical aspects $(p<0.01)$. The larger the size of the class, the more negative the experience was. Age did not correlate with physical environmental aspects.

\subsection{Students' view of the lecturer}

When considering the summated positive scores, lecturer characteristics such as respect for students (79.8\%), being an expert in their field (79.2\%), making time to consult with individual students out of class (72.9\%), motivational effect (72.8\%) and enthusiasm (69.6\%) were most highly rated by students when the lecturer was seen as able to facilitate engagement in the class. Students said that they felt motivated to attend classes when the quality of lecturing is high. Kyne (2010) refers to teacher competence, especially to facilitate engagement in the classroom, on the extent to which students benefit from attending a class.

\subsection{Student learning}

The results indicated that $52.3 \%$ of the students take control of their own learning. Although some respondents $(28.4 \%$ summated) felt that they are only taught the basic facts, which do not enable them to apply theory to practice, $51.3 \%$ of the respondents feel confident that they will be able to apply what has been learned in class. This is encouraging and seems to reflect the agency and commitment of many of the students. Only a few students prepare for class regularly (5.7\% - 171 out of the 2458 students who responded to this question). This suggests a lack of academic engagement outside the classroom. ANOVA statistics indicated that there was no statistically significant difference across the various year groups, ages or class sizes regarding their experience of learning in a large class.

\subsection{Assessment}

Several students (51.3\%) said that they found the lecturer accessible for discussion on assessment queries, but 25.4\% complained that they do not get regular feedback on their assignments. Feedback is a key mechanism for the motivation of students and acts as an aid for deeper learning (Kyne 2010). Although some students (26.2\% summated) feel they have to wait too long for assessment marks, $49.5 \%$ of the students reported that the feedback helps them to know what the gaps in their knowledge are and $22.7 \%$ of the respondents believe that the exam results are an accurate reflection of their knowledge about the topic. A proportion of the participants in this study (22\%) just want to be told what to learn and then write the examination.

There was a moderately significant difference in the experience of assessment by students in the different year groups $(p<0.05)$, with third year students being more dissatisfied than first year students. There was no significant 
correlation between assessment and age of the respondents or class size.

\section{Discussion and Conclusion}

Overall the results reflect that the large teaching experience has weakened the quality experience of learning for a vast majority of students in the South African experience.

The research reflects that two different student experiences in the large class environment

occurs which can be seen in Example A and B. Further the research results highlighted that the student experience of large class environment is directly related to the role of the lecturer and the ability of the lecturer to facilitate learning.

Example A: The role of the lecturer in relation to the student experience of the large class environment.

\begin{tabular}{|c|c|}
\hline \multicolumn{2}{|c|}{ When the lecturer is excited about the course content and was prominent in class (Wenglinsky2000) } \\
\hline $\begin{array}{l}\text { Student Experiences of the Large Class } \\
\text { Environment: } \\
\text { - Students were motivated to attend the lecture } \\
\text { and there is a high percentage of participation } \\
\text { by students; } \\
\text { - High engagement with the course material; }\end{array}$ & $\begin{array}{l}\text { "emphasises that the interaction among students, as well as between students and } \\
\text { the lecturer should be of high quality, otherwise it could result in the students failing } \\
\text { or dropping out". (Tinto 2007); } \\
\text { "Therefore the ideal is to create an environment in which students are encouraged to } \\
\text { not only focus on what should be learnt, but also on how they can learn it effectively" } \\
\text { (Clarket al 2008; Bovilla et al 2011). }\end{array}$ \\
\hline - High regard for the lecturer as subject expert & $\begin{array}{l}\text { " students view lecturers as part of the structural resources - although as a resource } \\
\text { for information" (Gorsky \& Caspi 2005). }\end{array}$ \\
\hline
\end{tabular}

The large class environment as reflected in Example A is largely beneficial for students who are able to study on their own and engage with the learning material with limited guidance from the lecturer.

Example B: The role of the lecturer in relation to the student experience of the large class environment.

\begin{tabular}{|c|c|}
\hline \multicolumn{2}{|c|}{ When the lecturer is unable to facilitate with excitement and is not prominent in the class. (Rowe 2011) } \\
\hline $\begin{array}{l}\text { Student Experiences of the Large Class Environment. } \\
\text { - Students often attend lectures irregularly view attending } \\
\text { large classes a waste of time and often drop out; } \\
\text { - Students become passive and do not participate in the } \\
\text { lecture; } \\
\text { - The entire new experience is confusing and prefer a } \\
\text { surface level approach to learning that only focuses on } \\
\text { knowing what should be learnt and when to write the } \\
\text { exams; } \\
\text { - Inhibited to ask questions in class and find it hard to } \\
\text { approach and talk to the lecturer and experience feelings } \\
\text { of anonymity }\end{array}$ & $\begin{array}{l}\text { "Central to good teaching is ensuring that the correct teaching and learning } \\
\text { approach occurs within the appropriate context and the lecturer achieves } \\
\text { the instructional goals within the teaching and learning context" (Mulryan- } \\
\text { Kyne 2010). } \\
\text { " limited exchanges occurring between students and lecturers with the } \\
\text { consequence that students remain anonymous and become passive" (Kyne } \\
\text { 2010); } \\
\text { "Without appropriate engagement with lecturers, students often experience } \\
\text { difficulty when make meaning of the subject field that they have not been } \\
\text { previously exposed to" Kuh et al (2010); Wolf-Wendel et al (2009); } \\
\text { "A large classroom setting is not conducive to the development of } \\
\text { interpersonal dialogue as a significant mode of dialogue that ensures }\end{array}$ \\
\hline
\end{tabular}

The large class environment as reflected in Example B is largely non-beneficial for students who are not equipped with the skills needed for self-regulated learning. Not attending classes exacerbates the dilemma of students who already struggle to make meaning of large amounts of factual information without guidance from the lecturer. In essence, these students require the "how to" but this is made difficult by the circumstances they find themselves in within a large class setting. This is further outlined by the OECD (2008) who states that the lecturer as part of the whole setting contributes to the level of interaction in the class.

Students reflected both in Example A and Example B that they are impacted by the noise levels within the large class environment when students enter the class late, which interrupts those who are trying to pay attention to the lecturer. The poor visibility of the presentation adds to the feeling that the class is not a meaningful experience. This is further supported by by Ward and Jenkins (1992) who explains that that some of the problems experienced by lecturers include dealing with large numbers of students entering and exiting the lecture room, which often results in teaching sessions starting late, dealing with noise levels during in-class tasks and dealing with the large volume of marking and student feedback.

Students believe that relationships with the lecturer and fellow students could help them to develop their skills and that the role of the lecturer is important to assist them in becoming subject specialists as well develop them in 
communicating effectively, have strong interpersonal and social awareness, become creative problem solvers and are able to display well-developed leadership skills. Students stated that if they do not receive regular feedback from lecturers, it might influence their level of confidence negatively and affect their ability to translate theory into practice. In a large class, students often have very little contact with the lecturer and with fellow students, and individualised feedback is usually a challenge. This is outlined by Grosky et al (2011) who states that a large classroom setting is not conducive to the development of interpersonal dialogue as a significant mode of dialogue that ensures teaching and learning. There is a reciprocal relationship amongst the three core findings of the study: students' level of independence, required competencies and skills which enable them to cope with a large class lecture, their preference for lectures and their view that the lecturer must be prominent in class.

Since students mentioned the need for interaction with peers, it is recommended that further research should focus on the value of teaching and learning methods that foster the development of strong communication and interpersonal skills as well as creative problem solving within the large class setting.

Ultimately, central to the success of a large class teaching and learning session is the experience of each individual student who attends and participates in these classes. This places special focus on the needs of the student in a large class setting and strengthens the notion that the voice of the student cannot be ignored when planning teaching and learning strategies.

\section{References}

Biggs, J. (1992). Aligning teaching for constructing learning. The higher education academy

Biggs, J. (1999). What the student does: Teaching for enhanced learning. Higher Education Research \& Development, 18(1): $57--75$.

Bovilla, C., Cook-Satherb, A., \& Felten P. (2011). Students as co-creators of teaching approaches, course design and curricula implications for academic developers. International Journal of Academic Development, 16(2): 133--145.

Carbone, E., \& Greenberg, J. (1998). Teaching large classes: Unpacking the problem and responding creatively. In To improve the academy:Resources for faculty, instructional and organizational development, ed. M. Kaplan, 311-316. Stillwater, OK: New Forums Press and Professional and Organisational Development Network in Higher Education.

Clark, M.C., Nguyen, H.T., Bray, C. \& Levine, R.E. (2008). Team-based learning in an undergraduate nursing course. Journal of Nursing Education, 47(3): 111-117.

Engelbrecht, L.V. (2003). Best practice of co-operative education. (NRF Project Ref: 15/1/5/2/000:44). Fielding, M. (2001). Students as radical agents of change. Journal of Educational Change, 2(3): 123--141. Gibbs, G. (1992). Improving the quality of student learning. London: Technical and Education Series.

Gorsky, P., \& Caspi, A. (2005). Dialogue: A theoretical framework for distance education instructional systems. British Journal of Educational Technology, 36(2): 137--144.

Gorsky, P., Caspi, A., \& Trumper, R. (2006). Campus-based university students' use of dialogue. Studies in Higher Education, 31(1): 71 -87. Harpp, D. (1994). Special problems of big classes: Some common sense solutions. Journal of Chemical Education, Vol. 71(8): 629--631. Jenkins, A. (1992). Active learning in structured classes. In Gibbs and Jenkins 1992

Kuh, G., Kinzie, J., Shuh, J.H., \& Whitt, E.J. (2010). Student success in college: Creating conditions that matter. San Francisco, CA: Jossey Bass. Mihans, R., Long, D., \& Felton, P. (2008). Power and expertise: Student-faculty collaboration in course design and the scholarship of teaching and learning. International Journal for the Scholarship of Teaching and Learning, 2(2): 1--9.

Mulryan-Kyne, C. (2010). Teaching large classes at college and university level: Challenges and opportunities. Teaching in Higher Education,15(2): 175--185.

Nicol, D.J., \& Boyle, J.T. (2003). Peer instruction versus class-wide discussion in large classes: A comparison of two interaction methods in the wired classroom. Studies in Higher Education, 28(4): 457--473.

OECD (Organisation for Economic Cooperation and Development). (2008). Education at a glance: Indicators. Paris: OECD. Ramsden, P. (2003). Learning to teach in higher education 2nd ed. London: Routledge-Falmer.

Rowe, A. (2011). The personal dimension in teaching: Why students value feedback. International Journal of Management, 25(4): 343-344. Rudduck, J. (2007). Student voice, student engagement and school reform. In International handbook of student experience in elementary and secondary school, eds. D. Thiessen and A. Cook-Sather, 587-610. Dordrecht, The Netherlands: Springer.

Tinto, V. (2007). Research and practice of student retention: What next? Journal of College Student Retention, 8(1): 1--19.

Toth, L., \& Montagna, L. (2002). Class size and achievement in higher education: A summary of current research. College Student Journal, 36 (2): 253-261.

Ward, A., \& Jenkins, A. (1992). The problems of learning and teaching in large classes. In Teaching large classes in higher education: How to maintain quality with reduced resources, eds. G. Gibbs and A. Jenkins, 23-36. London: Kogan Page.

Wenglinsky, H. (2000). How teaching matters: Bringing the classroom back into discussions of teacher quality. Princeton, NJ: Milken Family Foundation and Educational Testing Service.

Wolf-Wendel, L., Ward, K., \& Kinzie, J. (2009). A tangled web of terms: The overlap and unique contribution of involvement, engagement, and integration to understanding college student success. Journal of College Student Development, 50(4): 407--428.

Yang, Y.T.C. (2008). A catalyst for teaching critical thinking in a large university class in Taiwan: Asynchronous online discussions with the facilitation of teaching assistants. Educational Technology Research and Development, 56(3): 241--264. 